Journal of NELTA Gandaki (JoNG)

(A peer reviewed Open Access Research Journal)

ISSN: 2676-1041 [Print] E-ISSN 2822-1559 [Online]

Vol. IV Issue (1-2) November, 2021, pp. 1-18

eJournal site: www.nelta.org.np/page/gandaki

\title{
Awareness and Initiatives on Language Policy in Local Governments
}

Basanta Kandel

\begin{tabular}{|c|c|}
\hline & 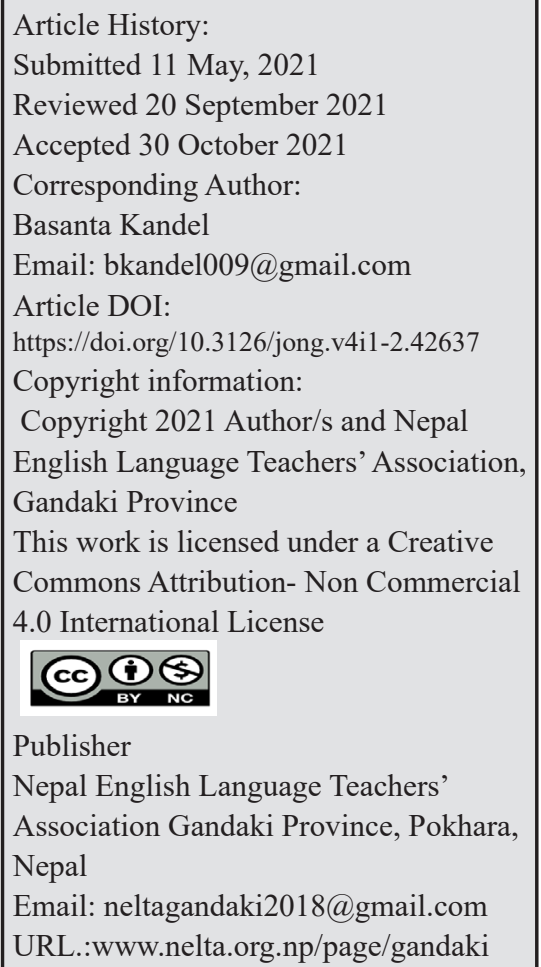 \\
\hline
\end{tabular}

Abstract

In Nepal, the Constitution of Nepal 2015 has abolished the centralized ruling system and established federalism which has opened up new insights into language policy issues. The Constitution empowers local government for language policy and planning, protection, promotion and use of languages, and scripts. Applying the ethnographic observation of the qualitative method, this study explores the awareness and initiatives of Nepali policymakers and language policy arbiters for the creation of language policy in local governments. Using purposive sampling, the study situates in two local governments of Gandaki Province, Nepal. The information collected through unstructured interviews, ethnographic observation, and informal interaction with language policymakers and arbiters has been analyzed and interpreted employing multiple methods. The findings show that local policy makers and actors impose multiple ideologies, therefore, language policy has become a contested issue and created a new public debate in the changing political-social and multilingual context of Nepal. Gradually, there is an increasing awareness on creating language policy, and constructive initiatives have taken for preservation and promotion of languages which is a positive way forward in the local governments by policymakers and arbiters.

Keywords: awareness, ideology, initiative, local governments, language policy.

\section{Introduction}

Federal Democratic Republic Nepal is a juncture of linguistic diversity. The Constitution of Nepal (2015) preamble states that Nepal is a multi-ethnic, multi-lingual, multi-religious, multi-cultural country having diverse regional characteristics. The country has diverse linguistic heritages that stem from four 
major genetic language groups: Indo-European (Indo-Aryan), Sino-Tibetan (Tibeto-Burman), AustroAsiatic, and Dravidian language families while Kusunda is a language isolate. The Indo-Aryan language family consists of 48 languages (82.1\%), Tibeto-Burman exhibits 68 languages (17.3\%), Santhali, Munda, and Kharia are three languages from the Austro-Asiatic family (0.19\%) (CBS, 2011), and Jhangar and Kisan are two languages in the Dravidian language family $(0.13 \%)$. Nepali is the official language in the country that supply as lingua franca among native and non-native speakers. The regional languages Bhojpuri, Maithili, Tharu, Awadhi are spoken in the flatland i.e. Terai, and varieties of Tibeto-Burman languages like Magar, Gurung, Rai, Limbu are spoken in Hilly and Mountain areas. The country has 123 languages (but Language Commission Nepal [LCN], 2020 reports 131) and 125 ethnic groups, and 10 major religious wings (CBS, 2011). Correspondingly, the LCN announces that only 19 languages are in a safe zone that has over one hundred thousand speakers but more than 37 languages are in endangered condition. Besides, Ethnologue (2019) informs that of 122 living languages in Nepal, 109 are indigenous, and 13 are non-indigenous, among them, 8 are institutional, 18 are developing, 28 are vigorous, 58 are in trouble, and 10 are dying. Moreover, LCN (2019) informs all the provinces in Nepal have an excellent number of languages which reflects the unique feature of multilingual Nepalese society. According to the Yearly Report of LCN (2019), Province no. 1 has 106 languages, Province no. 2 enriches with 89 languages, Bagmati Province blesses with 113 languages, Gandaki Province deserves 88 languages, Lumbini Province has 85 languages, Karnali Province obtains 55 languages, and Sudur Paschim Province gets 85 languages. Since April 3, 2018, Nepal parts into 77 districts, 3 layers of government: federal, provincial (7 provinces), and local (753 municipalities) which consists of 6 metropolitan cities, 11 sub-metropolitan cities, 276 municipalities, and 460 rural municipalities for official works.

At present, the political transformation from monarchy to the Federal Democratic Republic has provided an ideological space for the local governments to address the issues of language policy creation by its stakeholders, and has brought innovative ambiance in the language policy and planning sector. For this purpose, the constitution has granted 22 absolute powers to local governments including preservation and promotion of language, script, art, culture, and other heritages (The Constitution of Nepal, 2015). The reformation of the political regime has opened up new insights and discourses concerning language policy and planning but is still contested. Therefore, the future of Nepal's language policy depends largely on how federal, provincial, and local governments manage the linguistic diversity of the country, and act for language policy and planning.

Keeping these linguistic scenario and political concerns in the backdrop, this study aims to explore awareness and initiatives of the language policymakers and arbiters to create language policy (Johnson, 2013a) in Federal Nepal, especially in the local governments. I observe the language policy in Federal Nepal is a recent agenda and one of the priorities and most-waited issues of the federal, provincial, and local governments. To my knowledge, no local government has created, interpreted and appropriated language policy till the date but have taken some initiatives on that. Currently, LCN has recommended for 11 languages as the official languages in seven provinces (LCN, 2021) but how and when the decision will implement is not clear. At present, the creation of language policy in local governments is a hot debate; 
however studies on the issue are limited. Available research work mostly focused on history of language policy from Rana-Panchayat-Constitutional Monarchy to the Multiparty Democracy system; therefore the situation necessitates in-depth research to reveal the real scenario and practices to create, interpret and appropriate language policy in federal Nepal, especially by the local governments. Moreover, I found fewer studies have been carried out on the issue but not in-depth; consequently, I feel a gap to accelerate this study and conducted an ethnographic observation (McCarty, 2011) on language policy.

Therefore, this issue dragged my attention, and intended to conduct a 'critical ethnography' (McCarty, 2011; Carspecken, 1996) research on language policy issues in changing social and political context of Nepal which could be relevant to all the stakeholders. Further, I was interested to carry out the study because of these reasons; first, the place where I live is multilingual, multiethnic, and socially diversified, second, the political transformation in the country and the ideological space to the local government for adjusting the issues of languages and LPP, and third, my curiosity to examine the local level policymakers and arbiters engagement in the language policy creation, implementation, and appropriation processes.

The findings of the study contribute to aware and ignite the language policymakers, arbiters, agencies, researchers, government and bureaucrats, and politicians for creating the language policy at local governments. It benefits language policymakers and arbiters to develop the strategies and processes for creating language policy in local governments concerning the principle of federalism. And, it may support interested researchers as well.

\section{Review of Literature}

For strengthening the knowledge of language policy and ideology, theories and principles, literature, and researches in the field, I have reviewed a variety of newspapers, books, articles, journals, theses, dissertations, policies, websites, online from home and abroad, and put forward here. Based on the literature review, I have stated my understanding related to language policy, ideology, and the process of language policy creation in the following subsections.

\section{Language Policy and Ideology}

Language policy involves legitimizing languages or language varieties in the domains of formal communication such as education, administration, and media, and so on. It concerns what languages are to be used where, when, and by whom, and also what choices in grammar, vocabulary, genre, and style are appropriate in particular contexts. These decisions grant certain language varieties from higher to lower prestige, determining which ones are official, standard, and national language (Shohamy, 2006; Farr \& Song, 2011). Next, language ideology refers to the social, cultural, political conceptions/beliefs of personhood, citizenship, morality, quality, and value about language (Farr \& Song, 2011). Language ideology and language policy are inseparable; that is, language ideology inevitably informs policy. Ideology connects language policies and practices with sociopolitical issues at local, national, and global levels (Phyak, 2016). He advocates that language ideology as a constellation of human consciousness, values, attitudes, discourses, and epistemologies about language and language policies (p. 34). Therefore, 
"language ideologies are thus best understood as beliefs, feelings, and conceptions about language that are socially shared and relate language and society in dialectical fashion" (Piller, 2015, p. 4) for example, the ideology of "one nation, one language" is the belief that monolingualism is important for social harmony and national unity. Language policy and ideology are intricately related that the concept of one cannot be made clear without reference to the other. The following subsections discuss a brief survey of language policy in Nepal from the past to the present.

\section{Language Policy in Nepal}

Language policy in Nepal has a long history and trajectory; therefore, I have set them into two broad time references; Language Policies before Federalism, and Language Policies in Federalism.

\section{Language Policies before Federalism}

Language policy in Nepal before Federalism has diverse experiences. Weinberg (2013) mentions three broad time eras; Rana regime era: before 1950, Panchayat era: from 1950-1990, and Democratic era: after 1990. The major concerns of these eras in line with language policy are briefly discussed.

\section{Rana regime era: Before 1950}

Here, I outline a brief historical background of language policy in Nepal before 1950 which is considered the first period. During the time, the Kot Massacre of royal family members and advisers in 1846 escorted to the establishment of the Rana authoritarianism. The Rana rulers were not interested in developing the feelings of nationalism that often inspire the imposition of national language policies (Burghart, 1984). Further, they were opposed to widespread education, therefore, did not set language-ineducation policies. The first statement of language policy in Nepal, made in 1905, supposedly established Nepali as the official language of law and government with the declaration that only documents written in Nepali were legal for use in courts (Eagle, 1999). At the same time, Rana rulers declared Nepali the only permissible court language and English-language education for their children.

The first Rana ruler, Jung Bahadur Rana, after his visit from England in 1850, established the Durbar (Palace) School, an English medium school open to Rana family members. Besides, there was religious schooling in Hindu pathshalas and Buddhist gompas, using the mediums of Sanskrit and Tibetan respectively (Eagle, 1999; Phyak, 2011). Educational policy under the Ranas served to limit education to elites, mostly their Rana family members where the language of education was English. In terms of language policy, the Ranas appear to have been interested in maintaining their monopoly on English proficiency, a trend common to elites worldwide (May 2012). In a similar vein, Giri (2011) states 'the Rana autocracy introduced the 'muluki ain' (the Code of the Nation, enacted in 1854) meant for administrative reforms but used as an administrative tool to promote and strengthen Nepali language and cultural hegemony' (p. 209). Writings in, and publication and promotion of, any other languages than Nepali were banned during Rana autocracy (Shaha, 1990). Ranas (1846-1950) gave special protection to the Nepali language and encouraged its modernization and standardization, undermining the rest of the languages of Nepal (Dahal, 2000). During the Rana period, the standardization of literature, dictionary preparation/making, and codification in Nepali were encouraged, and 'Nepali Bhasa Prakashini Samiti' 
(Nepali Language Publication Committee) performed several works in this direction, and Nepali, thus, received special protection.

\section{Panchayat era (1950 -1990)}

The second period of language policy in Nepal began when Rana's rule ended in 1950 with the restitution of power of the king. During the period, Nepal's government became interested in cultural unification for the first time. The slogan of 'ek bhasha, ek bhesh, ek dharma, ek desh' (one language, one way of dress, one religion, one nation) summarized the goals of the Panchayat government, which attempted to spread Nepali, Hinduism, and other symbols of the nation throughout the country to create a unified national identity (Rai, et al., 2011; Whelpton, 2005). Further, King Mahendra adopted the melting pot approach on the belief that all Nepalese should be given a single identity: Nepali. He attempted to achieve this goal through an emphasis on unifying symbols such as Nepali nationalism, the monarchy, the Nepali language, Nepali dress, and Hinduism (Dahal \& Ghimire, 2012). The goal was an assimilation of people with varied cultural and linguistic practices into a Nepali identity based on the cultural practices of elite, high-caste hill Hindus (Onta, 1996a). Education was an important tool for reaching this end. Establishing widespread schooling was an immediate priority of the new government in 1950, and new structures of educational administration were set up shortly after the establishment of democracy.

\section{Democratic era (1990-2014)}

This is the third period in history when the Panchayat system ended accompanied by widespread protests for democracy in 1990. The king agreed to a new constitution which recognized Nepal as a multicultural and multilingual country. The Constitution of 1990 enclosed a major shift in language policy at the constitutional level, stating:

(1) The Nepali language in the Devanagari script is the language of the nation of Nepal.

The Nepali language shall be the official language.

(2) All the languages spoken as the mother tongue in the various parts of Nepal are the national languages of Nepal. (Constitution of Kingdom of Nepal, 1990)

This was the first time that languages other than Nepali received constitutional recognition as lawful elements of the nation. At the same time, this formulation maintains the supremacy of Nepali over other languages spoken in the country by keeping Nepali as the language of the nation (Phyak, 2011). The 1990 Constitution was also the first time that educational and cultural rights were explicitly extended to Nepal's minorities in the constitution, though again these provisions were not entirely straightforward. Despite the lack of clarity of certain provisions, the Constitution of 1990 was a major step forward for the inclusion of languages other than Nepali in education. The Constitution of 1990 remained in effect for seventeen years before being replaced by the Interim Constitution of 2007. The Interim Constitution 2007 has addressed the use of local languages at the community level which states:

(1) All the languages spoken as mother tongues in Nepal are the national languages of Nepal.

(2) The Nepali language in the Devanagari script shall be the language of official business.

(3) Notwithstanding whatever is written pursuant to clause (2), the use of mother tongue in the 
local body or office shall not be considered a barrier. The state shall translate the language used for such purpose into the language of official business for the record.

To sum up, language planning and policy writing in Nepal before federalism represents Nepal's language policy history as a journey of three stages: before 1950; between 1950 and 1990; and after 1990. The subsequent discussion sketches language policy in federal Nepal.

\section{Language Policies in Federalism}

Federalism and language policy have been a disputed and contested issue in Nepal because of recent socio-political-geographical reconstruction. Here, the issue is presented briefly in two themes: the present socio-political context of Nepal, and language policy in federal republican Nepal.

\section{The present socio-political context}

The interim parliament passed a bill making Nepal a federal republic on 28 December 2007 with a president as the head of state abolishing the centuries-old monarchy. After the election, the country got Ram Baran Yadav as the First President who served from 23 July 2008 to 29 October 2015. In reality, it was the landmark in history that paved the foundation for the federal system. The first meeting of the first Constituent Assembly held on $15^{\text {th }}$ Jestha 2065 B.S. declared Nepal as a "Federal Democratic Republic Country". At the present, Mrs. Bidhya Bhandari leads the country as the second President for the second term since March 2018. The incumbent Prime Minister Sher Bahadur Deuba is the $28^{\text {th }}$ prime minister in 29 years; cementing Nepal's transformation from the Hindu monarchy to a federal republic. At this time, the government has been processing and managing for three levels of government, restructuring the civil services, amending over 400 existing acts, and determining the division of funds, functions, and functionaries. The form of governance of Nepal is a multi-party, competitive, federal democratic republican parliamentary system based on plurality. The country has three layers of government, that is, Federal, Provincial and Local.

\section{Language Policy in Federal Republican Era}

The 'Fourth Period' in language policy in Nepal (my perception) was instigated after the country was formally announced as a federal republican in 2015. As a multilingual country, the Constitution 2015 announces the language policy issue and provisions in the article (6) and (7);

Article 6: All languages spoken as the mother tongues in Nepal are the languages of the nation.

Article 7: (a) The Nepali language in the Devnagari script shall be the official language of Nepal.

(b) A State may, by a State law, determine one or more than one languages of the nation spoken by a majority of people within State as its official language(s), in addition to the Nepali language.

(c) Other matters relating to language shall be as decided by the Government of Nepal, on recommendation of the Language Commission.

(Constitution of Nepal, 2015)

The constitution further states rights relating to education and language in article (31), and the provision of the right to language and culture article (32). In the same vein, the constitution assures full- 
fledged rights and responsibilities to the provincial and local governments for 'protection, development, and use of languages, scripts, cultures, fine arts, and religions' (The Constitution of Nepal, 2015, Schedule $6 \& 8$ ). These provisions in the constitution have given the freedom to the state, province, and local level to make and plan the policies regarding the language, culture, script, and arts. Therefore, the future of Nepal's language policy depends largely on how federal, provincial, and local governments manage the linguistic diversity of the country. The government has the responsibility to create and implement language policy and to ensure the linguistic and cultural rights of the citizen.

\section{Language Commission Nepal (LCN)}

For the protection, promotion, and development of languages in Nepal, the constitution 2015 has furnished a new provision to establish Language Commission in article 287. The functions, duties, and powers of the Language Commission in sub-clause (6) are:

(a) to determine the criteria to be fulfilled for the recognition of the official language and make recommendations on languages to the Government of Nepal,

(b) to make recommendations to the Government of Nepal, on the measures to be adopted for the protection, promotion, and development of languages,

(c) to measure the levels of development of mother tongues and make suggestions to the Government of Nepal, on the potentiality of their use in education,

(d) to study, research and monitor languages.

(Language Commission Nepal, 2015)

Further, the sub-clauses $(7,8$, and 9) state that the LCN should complete its task within five years, and establish a branch in each state. Therefore, the constitution has addressed sovereign powers to federal, provincial, and local levels (i.e., rural municipalities, municipalities, sub-metropolitan, metropolitan, and district assembly) for the creation of language policy. As a result, LCN has announced 11 languages as the official languages in the 7 provinces (Rai, 2021) as an example of 'multilingual turn' (May, 2014) which offers a critique of an alternative to dominant monolingual theories, polices, ideologies, pedagogies and practices. The announcement has increasingly challenged bounded, unitary, and reified conceptions of languages and related notions of 'native speaker' and 'mother tongue'. Phyak (2016) advocates that by recognizing complex linguistic diversity as natural condition of human society, this 'turn' questions the relevance of dominant language ideologies such as 'native speaker', 'monolingualism', and 'standard language', and reconstitutes language as a dynamic, flexible, and fluid phenomenon (May, 2014). In the context of Nepal, the recent 'turn' in the language policy and ideology has altered the superiority and authority of Nepali and English languages, and has spaced the alternative ideologies and epistemic stances in multilingual policies and ideologies. Therefore, the multilingual turn in Nepal has challenged the monolingual normativity in language policies and practices and reimagines alternative ones which recognize the 'multicompetence' 'multiliteracies', and 'multilingual identity' of multilingual learners (Phyak, 2014: 27).

In the same vein, various researchers and writers in Nepal have been raising awareness and 
making responsive to the three tiers of governments, language policymakers, agencies, and agents regarding language policy and planning issues. Sapkota (2012) relates experiences of federal countries: India, Canada, and South Africa, and suggests that Nepal can adopt a tri-lingual policy. Kandel's (2013) ethnographic study explores that family is the major domain for language policy, use, and choices which is influenced by dominant culture and language, migration and urbanization, inter-caste and inter-ethnic marriages, dialectal variations, and discriminatory language-in-education policy and practice. Phyak's (2016) engaged ethnographic study of language policy contributed to decolonizing language ideologies and reimagining an equitable multilingual education policy in Nepal, especially empowering Limbu indigenous teachers, youths, and villagers to uncover colonial ideologies of language, literacy, epistemologies, and building alternatives policies which legitimize their fluid multilingual practices.

Yadav (2017) emphasizes that language planning in Nepal has been largely dominated by the political scenario and embraced by the global ideology. He states the English language needs to be taught on equal footing as a subject in Federal Nepal. Tumbahang (2019) writes the Nepali language written in Devanagari shall be the official language of all provinces as Nepali has the majority of the population in the country. He recommends the language policy should be created based on a numeric majority of the population in all the Provinces. Phyak and Ojha (2019) critically analyze the historical trajectories of Nepal's language policies and assert that the future of Nepal's language policy depends largely on how federal, provincial, and local governments manage the linguistic diversity of the country, and for the creation, interpretation, and appropriation of language policy all the levels of government should be responsible. Poudel and Choi (2020) critically reflect that parliamentarians, lawmakers, and policy makers' diverse ideological orientations on language policies, as well as the interest of respective religion, castes, cultural groups, and ethnicity they represent have influenced the LPP processes in Nepal.

The reviewed theoretical, conceptual, empirical, and policy reviews on language policy and planning from home and abroad have greatly inspired and informed me theoretically and practically to my understanding of the area, and to accelerate the study in the Nepalese context. Also, several books, articles, journals, dissertations, and websites have strengthened me to make the research more comprehensive and logical. Taking the fundamental knowledge and reviewing earlier research studies, I outlined the theoretical and conceptual framework, prepared research design and methodology to gear up the study. Though various studies have been taken in a foreign context, I apprehend the need for a similar kind of study in the Nepalese context which can conduit the existing gaps in knowledge and add on a building block in the research foundation in the area of language policy in local governments.

\section{Conceptual Framework}

This research is informed by the theoretical foundations of Johnson's (2013a) view of 'Language Policy (LP) Layers', and McCarty's (2011) 'Ethnographic Observation'. Johnson (2013a ) portrays "LP layers- like processes of creation, interpretation, and appropriation- which occur at every level of policymaking". In this conceptualization, policies are first created as a result of intertextual and interdiscursive links to past and present policy texts and discourses. Johnson further states "once a policy 
has been created and put into motion, it is open to diverse interpretations, both by those who created it and by those who are expected to appropriate it in practice" (p. 109). When the policy is created or developed, the interpreters interpret and finally appropriate (put into action) by the agents. These processes might line up with different levels of language policy (federal /creation, state/interpretation, local/appropriation), in reality, they can occur at every level; that is, language policies are created, interpreted, and appropriated within and across multiple levels of institutional contexts. Briefly, policies are created at multiple levels and in multiple contexts (national, state, city, community, school, family, and so on) then interpreted and appropriated by multiple language policy agents across multiple layers of policy activity (Johnson, 2013a: 108). Further, it declares that not every individual in each layer is equally powerful since some are positioned as arbiters while others are positioned and implementers of language policy (Johnson \& Johnson, 2014) therefore, LP activity may be the 'perennial challenge' (Hult, 2010 as cited in Johnson and Johnson, 2014) for the field.

Ethnography of language policy as a multimethod, multilayered, and multisided approach (McCarty, 2011), individual language users are (or should be) the agents to construct and manipulate the language policy, and they perform this role creatively and productively. Hornberger and Johnson (2007) had in mind when they introduced the "ethnography of language policy" as a method and theory of examining the agents, context, and processes across the multiple layers of language policy creation, interpretation, and appropriation. In Johnson's (2013) words, ethnography of language policy focuses on the role of the "agency of individuals to manipulate policy in creative and unpredictable ways" (p. 12). In the same vein, the ethnographic observation interprets language policy as a multilayered construct where power relations, social structure, economy, politics, and ideology are intricately interwoven (McCarty, 2011), and the researcher observes the life activities of the participants situating ethnographically. The exceeding literature reviews on language policy, theories, conceptual framework, and the succeeding methodology assisted to explore the awareness and initiatives of local governments and language policymakers in local governments.

\section{Methodology}

This study employs the ethnographic observation of the qualitative research corresponding to the interpretative paradigm. The paradigm suggests 'the reality is indirectly constructed based on individual interpretation and is subjective' (Cohen, et al., 2007). For the study, I used non-probability purposive sampling and collected the information from two local governments (i.e., Vyas Municipality and Myagde Rural Municipality), five policymakers, and four local people in two municipalities within six months' period. The study aimed to carry out in these municipalities since the sites constitute the significant population heterogeneity in terms of caste/ethnicity, language, religion, and culture; therefore, I found the area suitable for the study. To be specific, two local governments from Tanahun district were selected purposively, based on provincial location, ecological and geographical region, linguistic, ethnic, and cultural diversity. For ethnical consideration, I took consent, maintained anonymity to the research participants, and assigned codes for policy makers, ward chairs, and research participants respectively (e.g., PM 1, PM 2, WC 1, WC 2, RP 
1, RP 2). Then, I collected descriptions of the practices, maintained close consultations with stakeholders, reflected on the language policy issues, conducted the critical analysis of qualitative reporting, and took all together eight interviews including Mayor, Chair/Vice-chairperson, Ward Chairpersons, and local people. I accumulated the information using ethnographic observation, document analysis, and interview tools. For the analysis of information, transcription and coding to developing themes in step-by-step form making web-like illustration (Stirling, 2001), and critical discourse analysis (Fairclough, 1992) have been utilized to summarize the data to generate the meaning of participants' views.

\section{Results and Discussion}

The subsequent part explores, analyses, and interprets the awareness and initiatives on language policy creation at the local governments based on the empirical evidence drawn from the 6 months long ethnographic observation, particularly, the information gathered from language policymakers, arbiters, and concerned stakeholders, and discussed thematically within the border of objectives and research questions. The collected data have been broadly interpreted and analyzed into four broad themes: awareness of language policy, ideological becoming on language policy, initiatives on local language policy, and consciousness on language conservation linking with existing theories, and excerpts of the participants.

\section{Awareness of Language Policy}

After the promulgation of the constitution in 2015, the local governments in Nepal have been functional for four years that guaranteed 22 autonomous rights and responsibilities. To be specific, the constitution has affirmed local governments for 'protection, development, and use of languages, scripts, cultures, fine arts, and religions' (The Constitution of Nepal, 2015, Schedule 6 and 8). The three layers/ levels of governments: federal, provincial, and local governments have proportionate amount of decision and policy-making power assured by the constitution. Therefore, each local government and its wings, language policy makers, agencies, agents, and actors are equally responsible for language and language policy issues. Despite the local governments' territories are multilingual and multiethnic but seem to lack appropriate discussion, interaction, study, and research on language policy and planning issues, and have less awareness of language. Language awareness (LA) does not mean learning a multiplicity of languages, but coming into contact with many different languages to understand the way language works and the function of languages in society and institutions (Helot \& Young, 2006). However, the policymakers express divergent views about the existing local languages and awareness in their wards and territories:

Some ethnic community come up with their plans to save their language and culture and we have given it a priority, at least in board meetings, by allocating plans and budgets...we have never been stingy in preserving folk culture and language. (From interview transcript, WC: 2)

I sensed that language policymakers and agencies have been gradually becoming aware of language policy issues and have developed intercultural competence and multilingual awareness (Byram, 1997; Helot \&Young, 2006) at local levels. For language policy awareness they consult the constitution, provincial and local government regulation acts, and policies, and other documents. The Chairperson of Myagde Rural Municipality (PM 2) asserts: 
For 4 years, I have been reading different documents published by federal, provincial, and other local governments; therefore, the awareness and knowledge in policymaking is gradually expanded in all the areas. But the newly formed local governments are more focused on physical development rather than policy creation. I have read about language policy issues and provisions there (in documents) and also plan to apply and create in my territory soon. (personal communication, October 15, 2019).

The policymakers in local governments have raised language policy and multilingual awareness to some extent, in contrast, the local people seem unaware of the constitutional provisions to the local governments on language policy issues since no voices have been raised till now. There still lacks the issues related to language, language policy and planning both in policy level and grass root level as a result the actors show their ignorance in the area. The ideology of the Mayor of Vyas Municipality (PM 1) corresponds with the arguments stated above:

Since we are somehow aware of language policy during four years period of local government operation but frankly to say, neither any language community has raised voices nor demanded to strengthen and promote their language since the territory has 31 languages in use (informal interview, November 19, 2019). The local government body has not yet decided on the official language policy, however, the majority of the people in the municipality use the Nepali language as an official language. There is an increasing demand for the English language side by side with Nepali in official settings (emphasis added).

Figures 1\&2: The landscapes of study sites (i.e. Vyas Municipality and Myagde Rural Municipaliy)
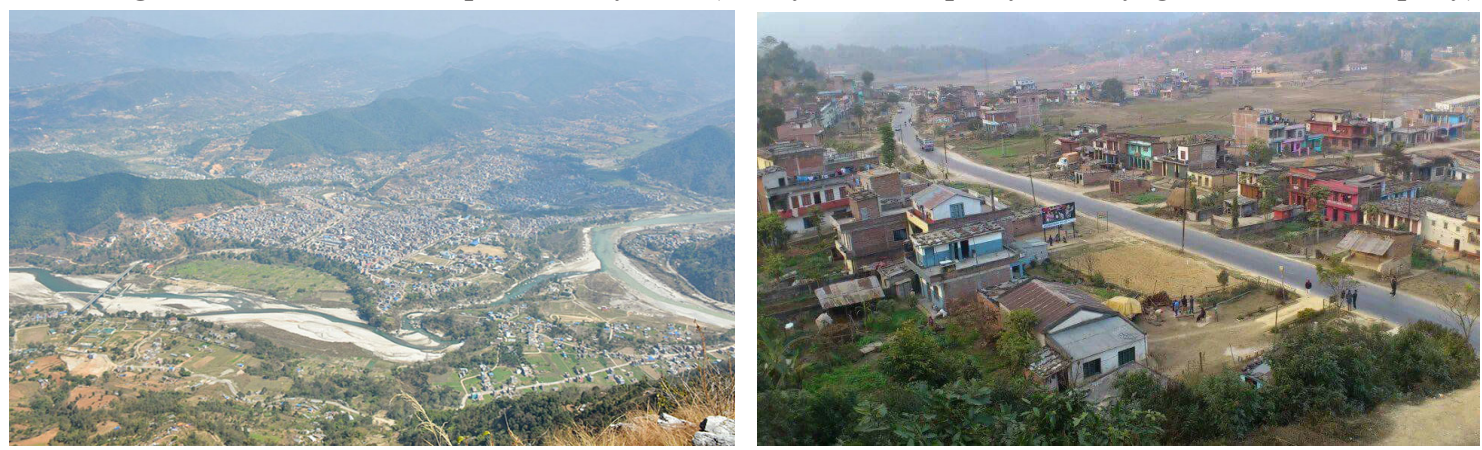

Moreover, the government, language policymakers, and arbiters' understanding and awareness of language policy creation seem fewer. Both the governments have been adopting the Nepali language for official purposes, despite, the territories are linguistically, culturally, and ethnically diverse. It seems that the policy makers in local governments practice and reproduce dominant nation-state and neoliberal language ideologies which has caused the construction of monolingualism (Phyak, 2016), and influenced 'monolingual mindset' (Clyne, 2005), and 'monolingual bias' (May, 2014). The constitution guarantees power to the local governments for creating language policy and planning, although, the issues still seem static and inactive, and the policymakers and agencies lack sufficient knowledge and awareness in it. 


\section{Ideological Becoming on Language Policy}

The ethnographically grounded informal interaction which I conducted with the policymakers and local people has raised 'critical consciousness' (Freire, 1970) of multiple language ideologies and informed them in reclaiming their identities as a knower and transformative agent for creating multilingual space in Federal Nepal. In particular, dialogic engagement contributed to 'ideological becoming' (Bakhtin, 1981; Ball \& Freedman, 2004) which represents the participants' critical awareness about the nation-state ideologies on language policy. After the 'dialogic engagement, my study participants developed 'ideological clarification' (Fishman, 2001; Kroskrity, 2009) about the neoliberal ideologies in both dominant and resistance language policy discourses, and got informed the processes of language policy creation at local governments and the roles of its agents and agencies to some extent. The Vice-Chairperson of Myagde Rural Municipality, PM 3 asserts:

Your conversation is much informative about language policy issues. We are clear enough about the federal, provincial, and local level language policy provision, rights, and responsibilities in the constitution, the local government regulation act from the dialogue with you. We will further talk to the policy-making experts and agencies soon (informal interview, October 18, 2019).

In the same vein, Magar and Darai residents at Vyas Municipality state with confidence: Language is our identity, and it is our prestige, therefore, we should preserve it for multiple reasons. We are called 'Magar' or 'Darai' because of our language and culture. To some extent, we are now ideologically becoming about the provision in the constitution, the roles of local government, language policymakers, and other stakeholders in the creation of language policy from the discussion. Accordingly, we will raise our actions and voices on the issue to the concerned (RP $1 \& 2$, informal interview, October 20, 2019).

The respondents' arguments reveal the meaning that local governments, language policymakers, agencies, agents, and arbiters need more interaction, discussion, debate for ideological becoming and clarification before, while, and after the creation of language policy. The more communication and sharing, the more ideologically becoming and clarification they can fabricate on language policy and planning issues.

\section{Initiatives on Local Language Policy}

The constitution of Nepal 2015 assures 22 absolute powers to the local government including the conservation and promotion of language, creating language policy, and planning, in this circumstance, some local governments have taken initiatives on local language policy in their territory. For example, Kathmandu Metropolitan City, Lalitpur Metropolitan City, and Kirtipur Municipality have decided to use Nepal Bhasa (Newari language) in local government offices and within the territory for official communications. Similarly, Ghorahi Sub-Metropolitan City decided to adopt the Tharu language as one of the official languages, and Birgunj Metropolitan City has decided to use the Bhojpuri language for the official purpose (Phyak \& Ojha, 2019). Recently, some local governments like; Falgunananda Rural Municipality in Panchathar, and Marid Rural Municipality of Sindhuli have developed the local level language policy. 
The provisions on language policy in the constitution have created a new public debate, initiated agencies and agents to create multilingual policies, and preserve dominant languages in the changing socio-political context of Nepal. But to the date, in Gandaki province, no local governments (among 85 governments) have so far decided about official language policy. Since the discussion, interaction, public hearing, and field research conducted in the region have ignited to move and work on the issue. The PM 1 adds with emphasis:

We have passed the directive of Vyas Pragyan Pratisthan (Vyas Municipal Academy) - a milestone process/body for the preservation, promotion, and development of language, culture, art, and architecture of this area, and allocated one million rupees budget for the research purpose (informal interview, April 10,2021). We plan to conduct massive research on language policy and the medium of instruction in education. We are drafting an act and implementing soon. We are positive and committed to promote and conserve local languages and schools like Sanskrit schools, Nepali medium schools, English medium schools, sign-language based schools, and Madarsha schools which are run in this region (emphasis added)

The growing awareness of language policy at local government has ignited its actors and arbiters for the initiation and creation of language policy documents. Similarly, one of the policy and lawmakers in Gandaki province (PM 4) informed that:

The state assembly has passed a bill "Gandaki Province Academy" for the protection of language and culture. The assembly discussed the bill clause by clause, passed with a majority of votes but has not been implemented yet. The bill emphasizes the preservation and promotion of languages and cultures of the Gandaki region (personal communication, April 12, 2021).

At present, out of 753 local governments in Nepal, half a dozen have decided and documented language policy in the respective territory but the majority of them have not been processed despite the governments and its wings have been functional for 4 years. The initiatives on language policy and planning in local government seem less satisfactory since it is an urgent agenda to be addressed and accomplished. The local governments should complete this responsibility within five years as stated in the constitution, though it seems to be unfulfilling by the stipulated time.

\section{Consciousness on Language Conservation}

Each local government in Nepal is linguistically and ethnically diverse; however the concerned authorities and stakeholders seem unaware and inactive to preserve and promote this social treasure. The government policies and documents greatly advocate in favour of linguistic and ethnic heritage but in the practice the language issue has been ever shadowed. Therefore, my research participants express worry for the preservation and promotion of local indigenous languages existed in the territories. To the concern, a massive discussion with its governing bodies, policymakers, actors, and agents should be bridged to make them aware of their 'linguistic and cultural capitals' (Bourdieu, 1991) in the territory. After the federal system in the country, the policymakers in local governments express their consciousness to the issues of language conservation, promotion and development since some languages in local level are in critical 
condition and near to death; in this milieu, the policy makers assured that:

Some years before, 'Darai' language was used exclusively in this area, but in recent years, growing trends of employment in the foreign countries, adopting Nepali and English as-a-medium of instructions in schools, feeling of humiliation to speak in mother-tongue, migrations from village to urban, inter-caste marriage, modernization, globalization process have caused the language in endangered condition. The language users have been decreasing day by day and the culture is being shadowed. We need to preserve, conserve and promote those languages (PM 1, personal communication, November 19, 2019).

In the same verge, two of the ward chairs in Vyas municipality claimed that the local authorities have performed the parental role to preserve language, ethnicity, and culture despite the unconcern of locals.

We are in favor of preserving the languages and cultures of the ward. But, let the community express its desire and come here. The ward is in favor of encouraging. If they don't show interest, there is no possibility. We say that the concerned stakeholders should be ready for this. Both the municipality and the ward are involved in it. Consciousness should be awakened; language and culture should be preserved... (From interview transcript, WC 1)

We have a responsibility to protect the language at the local level. We as parents should be more concerned with protecting the languages but people should be interested too. They should inspire their family to teach and preserve their language. If they teach it, they will know that it is our ethnic language, the traditional language. We have started promoting minorities' languages, castes, and tribes by linking with tourism, religions, and monasteries. (From interview transcript, WC 2)

The majority of the interview participants insisted that the local government should draft and prepare language policy including culture, ethnicity, and art and architecture. The conservation and promotion of linguistic and cultural capital in the local government is an urgent and ongoing debate. Tribal and ethnic groups have been demanding for ensuring their social, cultural, ethnic, and linguistic identity, therefore, language promotion, preservation issues have become political agendas in local governments (Phyak, 2016) and ideological awareness should be raised. Concerning the multilingual reality of the country, the new constitution has provisioned an open language policy and equal respect to all the languages without any restriction (Kandel, 2019) which should be utilized by local governments.

\section{Conclusion and Implications}

Language policy has become a more contested issue, created a hot dispute and dialogue about the status and role of local languages in the local governments of Federal Nepal. Gradually, there is an escalating 'ideological awareness' and 'ideological clarification' to language policymakers, agents, and arbiters on language policy issues. Language policymakers assured to adopt multilingual policy approaches in their territories, and have taken some initiatives. The increasing awareness of the conservation, preservation, and promotion of linguistic and cultural capital is a positive way forward by the local governments that creates an ideological space from 'monolingual norms' to 'multilingual turn'. Contrary, the vested and dominant language ideologies of policy makers and actors in the local government function as challenges 
for 'linguistic justice' and 'linguistic human right'. I argue that it is necessary to raise more critical awareness to language policymakers and its arbiters for creating acceptable language policy in local governments in harmony with constitutional and federal provisions.

While studying language policy issues and reviewing the related literature, I suggest there is a need for a collaborative effort to create language policy in local governments. I realized the need for more discussions on the issues, their challenges and opportunities, and way-outs in the field. After the observation and analysis of ideological awareness and initiatives on language policy creation in local governments, I came to know that policymakers, arbiters, and elites intend to devise their rooted ideology for strengthening their mother tongue policy in their region. Their concern and initiative on language policy are shaky and showy; in contrast, they aim to promote their own mother tongue rather others' tongue. They desire to be privileged access to political, economical, social, and cultural resources, and conversely, impede such access to speakers of other languages. Their ideology appears to uplift their mother tongue despite other languages seem critical that cause the languages near to extinction. The policy makers have been imposing supremacy of dominant language ideologies and epistemologies, and spacing among localindigenous-minoritized languages. As a result, the field of language policy has become more complex because of multilingual society, monolingual mindset, vested ideology, elites' supremacy, globalization, migration, ethnic and cultural diversity, and technology. Therefore, there is a need for serious discussions on how to connect peoples' linguistic and cultural repertoire and make liberal language policy and act for a positive way forward in the local governments. Additionally, the language policy actors and marginalized communities should engage themselves in decolonizing language ideologies by raising critical awareness of hegemonic language ideologies which the scholars call 'engaged language policy' that applied for equitable language policy creation, interpretation, and appropriation processes.

\section{Acknowledgments}

This article is based on my Ph. D. study at the Graduate School of Education, Tribhuvan University, Nepal. I express my deep gratitude to University Grants Commission, Nepal for providing 'Ph.D. Fellowship and Research Support 2020' for the study. Besides, I sincerely acknowledge my research Supervisor Prof. Bal Mukunda Bhandari, Ph.D. for his insights and excellent academic investments, and Aadikavi Bhanubhakta Campus, Tanahun (my employing institution) for indispensable academic support to accelerate my study. At the end, I owe a debt to all the respondents and participants of this study.

\section{References}

Bakhtin, M. M. (1981). The dialogic imagination: Fours essays. University of Texas Press.

Ball, A., \& Freedman, S. W. (Ed.). (2004). Bakhtinian perspectives on language, literacy, and learning. Cambridge University Press.

Bourdieu, P. (1991). Language and symbolic power. Polity Press.

Burghart, R. (1984). The formation of the concept of nation-state in Nepal. Journal 
of Asian Studies, 44(1), 101-125. https://doi.org/10.2307/2056748

Byram, M. (1997). Teaching and assessing intercultural communicative competence. Multilingual Matters. Central Bureau of Statistics. (2011). National Population and Housing Census 2011. [National Report]. http://www.unstats.un.org/unsd/demographic/sources/census/wphc/Nepal-Cesis-2011

Clyne, M. (2005). Australia's language potential. University of New South Wales Press.

Cohen, L., Manion, L, \& Morrison, K. (2007). Research methods in education. Routledge.

Constitution of the kingdom of Nepal. (1990). His Majesty's Government of Nepal.

Constitution of Nepal. (2015). The Secretariat of Constituent Assembly. Nepal Law Commission.

Dahal, R. K. (2000). Language politics in Nepal. Nepalese Studies, 27 (2), 155-190.

Dahal, D. R. \& Ghimire, Y. (2012). Ethnic federalism in Nepal: Risks and opportunities. Georgetown Journal of International Affairs. 13 (1), 71-78. https://www.jstor.org/stable/43134216?read

Davis, K. A., \& Phyak, P. (2015). In the face of neoliberal adversity: Engaging language education policy and practices. L2 Journal, 7(3), 146-166. https://doi.org/10.5070/L27323494

Eagle, S. (1999). The language situation in Nepal. Journal of Multilingual and Multicultural Development, 20(4-5), 272-327. https://doi.org/10.1080/01434639908666382

Ethnologue (2019). Languages of the World. Nepal Ethnologue. http://www.ethnologue.com

Fairclough, N. (1992). Discourse and social change. Polity Press.

Farr, M., \& Song, J. (2011). Language ideologies and policies: Multilingualism and education. Language and Linguistics Compass, 5 (9), 650-665. https://doi.org/10.1111/j.1749-818X.2011.00298.x

Fishman, J. A. (Ed.). (2001). Why is it so hard to save a threatened language? Can threatened languages be saved? Multilingual Matters.

Freire, P. (1970). Pedagogy of the oppressed. Continuum.

Giri, R. A. (2011). Languages and language politics: How invisible language politics produces visible results in Nepal. Language Problems and Language Planning, 35(3), 197-221. http://dx.doi. org/10.1075/lplp.35.3.01gir

Hélot, C., \& Young, A. (2006). Imagining multilingual education in France: A language and cultural awareness project at primary level. In Garcia et al. (Ed.), Imagining multilingual schools: Languages in education and glocalization, (PP. 69-90). Multilingual Matters.

Hornberger, N. H., \& Johnson, D. C. (2007). Slicing the onion ethnographically. Layers and spaces in multilingual language education policy and practice. TESOL Quarterly, 41(3), 509-532. https://doi. org/10.2307/40264383

Johnson, D. C. (2013a). Language policy. Palgrave Macmillan.

Johnson, D. C., \& Johnson, E. J. (2014). Power and agency in language policy appropriation. Lang Policy. 14(1), 1-23. https://doi.org/10.1007/s10993-014-9333-z

Kandel, S. (2013). Language choice and use in multilingual contexts of Nepal: An ethnographic study. [Doctoral dissertation, Jawaharlal Nehru University]. ProQuest Dissertations and Thesis Global.

Kandel, B. (2019). Globalization and its impact on English language in Nepal. The Journal of Aadikavi, 9 (1), 80-91. 
Kroskrity, P. V. (2009). Langauge renewal as sites of language ideological struggle: The need for ideological clarification. In J. Reyhner \& Lockard (Ed.), Indigenous language revitalization: Encouragement, guidance and lesson learned, 71-83, Northern Arizona University.

Language Commission Nepal. (2015). Language commission act. Nepal Law Commission.

Language Commission Nepal. (2019). Annual publication. Author.

May, S. (2012). Language and minority rights: Ethnicity, nationalism and the politics of language Routledge.

May, S. (Ed.). (2014). The multilingual turn: Implications for SLA, TESOL, and bilingual education. Routledge.

McCarty, T. L. (Ed.). (2011). Ethnography and language policy. Routledge.

Onta, P. (1996a). Ambivalence denied: The making of Rastriya itihas in Panchayat era textbooks. Contributions to Nepalese Studies, 23(1), 213-254. http://himalaya.socanth.cam.ac.uk/collections/ journals/contributions/pdf/CNAS 23_01_1 3.pdf

Phyak, P. B. (2011). Beyond the façade of language planning for Nepalese primary education: Monolingual hangover, elitism and displacement of local languages? Current Issues in Language Planning, 12(2), 265-287. https://doi.org/10.1080/14664208.2011.584203

Phyak, P. B. (2016). 'For our cho:tlung': Decolonizing language ideologies and (re)imagining multilingual education policies and practices in Nepal. (Doctoral dissertation, University of Hawai'i). ProQuest Dissertations and Thesis Global.

Phyak, P., \& Ojha, L. P. (2019). Language education policy and inequalities of multilingualism in Nepal: Ideologies, histories and updates. In A. Kirkpatrick \& A. J. Liddicoat (Ed.), The Routledge International Handbook of Language Education Policy in Asia, 341- 354. Routledge.

Piller, I. (2015). Language ideologies. In The International Encyclopedia of Language and Social Interaction. https://doi.org/10.1002/9781118611463/wbielsi140

Poudel, P. P. \& Choi, T. H. (2020). Policymakers' agency and the structure: the case of medium of instruction policy in multilingual Nepal, Current Issues in Language Planning, https://doi.org/10.1080/14664 208.2020.1741235

Rai, G. (2021, September 8). Eleven languages recommended in provinces (in Nepali). https://ekantipur.com/news/2021/09/08/163106136964166335.html?fbclid=IwAR337zY1

Rai, V. S., Rai, M., Phyak, P., \& Rai, N. (2011). Multilingual education in Nepal: Hearsay and reality. UNESCO.

Sapkota, S. (2012). Language policy in federal Nepal: Sharing from some federal states. Nepalese Linguistics, 27(1), 190-198. http://himalaya.socanth.cam.ac.uk/collections/journals/nepling/pdf/ Nep_Ling_27.pdf\#pa ge $=195$

Shaha, R. (1990). Three decades and two kings (1960-1990): Eclipse of Nepal's partyless Monarchic Rule. Sterling Publication.

Shohamy, E. (2006). Language policy: Hidden agenda and new approaches. Routledge. https://dx.doi. org/10.4324/9780203387962 


\section{Journal of NELTA Gandaki (JoNG) Vol. IV (1 - 2) November 2021}

Stirling, J. (2001). Thematic networks: an analytic tool for qualitative research. Qualitative Research. 1 (3), 385-405. https://doi.org/10.1177\%2F146879410100100307

The interim constitution of Nepal. (2007). Government of Nepal.

Tumbahang, G. B. (2019). Language planning in Nepal. http://therisingnepal.org.np/news/18507

Weinberg, M. (2013). Revisiting history of language policy: The case of medium of instruction i $\quad n$ Nepal: Working Papers in Educational Linguistics, 28(1), 61-80. https://repository.upenn.edu/ wpel/vol28/iss $1 / 6$

Whelpton, J. (2005). A history of Nepal. Cambridge University Press.

Yadav, L. (2017). Language planning and policy for equal footing and justice in federal Nepal. Journal of the Institute of Engineering. 13(1), 232-238.

Basanta Kandel is a Lecturer of English at Aadikavi Bhanubhakta Campus, Tanahun, and a PhD Scholar in Tribhuvan University. He is the Vice-chair of NELTA Tanahun, Member of IATEFL, and the Editor of vyasshree.com. He has published a dozen of articles, edited journals, and presented papers in national and international conferences. His areas of interests include language policy and planning, linguistics, and research methodology. 